\title{
ОРГАНІЗАЦІЙНЕ ОФОРМЛЕННЯ ДІЯЛЬНОСТІ ПРАВОСЛАВНИХ ЦЕРКОВНИХ БРАТСТВ ПОДІЛЬСЬКОЇ ГУБЕРНІЇ У ДРУГІЙ ПОЛОВИНІ ХІХ - ПОЧАТКУ ХХ СТ.
}

Анотація: Мета статті полягає у розкритті організаційних засад функціонування православних братств Подільської губернії упродовж другої половини XIX - початку XX ст. Наукова новизна - вперше на основі маловідомих архівних документів проаналізовано та розкрито спещифіку організащійного оформлення та функиіонування православних братств Подільської губернії. На прикладі окремих братств показано специфіку й особливості організації православних братств Подільської губернії.

Встановлено, що упродовж другої половини ХІХ ст. обставини заснування та подальшу діяльність православних братств на території Подільської губернії регулювали «Основні правила для заснування православних иерковних братств». Цей нормативний документ визначав $i$ контролював завдання, склад, напрями діяльності братств. На початку XX ст. у суспільнополітичному житті Російської імперії відбулися певні зміни, що, у свою чергу, вплинули на становище православних братств Правобережної України. Це внесло певні корективи у діяльність православних братств, оскільки церковне управління Подільської єпархії уклало та затвердило нові правила, що регулювали подальщу роботу цих братств.

Ключові слова: російський уряд, Подільська губернія, православні братства, організаційні засади, cmamym

Відродження діяльності православних братств у Подільській губернії упродовж другої половини XIX ст. було зумовлене бажанням уряду Російської імперії перешкоджати впливу та поширенню інших релігій на підконтрольних територіях Правобережної України. Діяльність церковних братств була направлена на укріплення російського самодержавства та зміцнення позицій Російської православної церкви. Відтак російський уряд мав на меті суворо контролювати їх виникнення та подальшу діяльність.

Сучасні історики надають пріоритет вивченню питання виникнення та розвитку братського руху у різних регіонах України. Зокрема, статті О. Сажок ${ }^{1}$ та I. Тимочко ${ }^{2}$ присвячені виникненню братств у Волинській губернії, В. Сергієнко ${ }^{3}$ дослідила причини

\footnotetext{
* Альошина Оксана Анатоліївна - кандидат історичних наук, доцент кафедри культурології та філософії Національного університету «Острозька академія» (Острог, Рівненська область, Україна);

ORCID: http://orcid.org/0000-0002-0893-3791; e-mail: oksana.alioshyna@oa.edu.ua

${ }^{1}$ Сажок O. Становлення і розвиток церковного братського руху у Волинській губернії у другій половині XIX на початку XX ст. Науковий вісник Східноєвропейського національного університету імені Лесі Українки. Історичні науки. 2013. Вип. 21. С. 33-38.

${ }^{2}$ Тимочко I. Провідні передумови просвітницько-громадської діяльності православних братств Волині (друга половина XIX - початок XX ст.). Актуальні проблеми вітчизняної та всесвітньої історії: збірник наукових пращь. Рівне, 2011. Вип. 22. С. 231-233.

${ }^{3}$ Сергієнко В. Система управління православних церковних братств Лівобережної України (1864-1917рр.). Часопис української історії. 2013. Вип. 27. С. 7-11.
} 
ïх заснування на Лівобережній Україні. Тематика, присвячена просвітницькій діяльності православних братств у релігійному житті Подільської губернії, представлена у публікаціях вітчизняних науковців О. Григорук ${ }^{4}$ та I. Опрі ${ }^{5}$. Проте вони опублікували низку статей, в яких не розкрито аспекти організаційного унормування та функціонування братств. У вітчизняній історіографії відсутні наукові розвідки, які б повністю висвітлювали означену тему. Залучення до обігу документів державних архівів і періодичних видань дало можливість показати процес організації й особливості оформлення православних братств у Подільській губернії вказаного періоду.

Мета наукової статті полягає у розкритті специфіки організаційного оформлення православних братств Подільської губернії у зазначений період.

Новий етап для відновлення та подальшого розвитку церковного братського руху розпочався тоді, коли російський уряд розробляв ідею щодо створення православних братств і на законодавчому рівні сприяв їхньому організаційному оформленню.

Погоджуємося із твердженням В. Сергієнко, що важливою передумовою створення урядом Російської імперії православних церковних братств була девальвація цінності Російської православної церкви як інституту, який дедалі більше дискредитував себе перед народом, зокрема, через здирництво, низькі професійні та моральні якості ї̈ служителів, співпрацю 3 царською владою тощо. Відповідно православні церковні братства були покликані налагодити комунікацію між православними парафіянами та кліром, щоб підвищити рівень толерантності до останніх, зокрема і до Російської православної церкви як інституту загалом ${ }^{6}$.

На сторінках тогочасних періодичних видань зазначалося, що головним завданням православних братств було «відродження православ'я в західноруському краї й очищення, наскільки можливо, грунту для православ'я від усяких домішок і здійснення виховної просвіти серед народу на християнських православних істинах» ${ }^{7}$

Церковнопарафіяльні братства створювалися з метою поширення серед населення духовної освіти шляхом заснування недільних та церковнопарафіяльних шкіл, проведення позабогослужбових духовно-моральних читань, розповсюдження книг, брошур і настановчих листків, особливо такі, в яких «розсудливо викриваються сектантські помилки» та пояснюється істина православної віри. Окрім цих завдань, вони здійснювали матеріальне забезпечення місцевих жителів у разі хвороб, бідності й інших жителів, які прийняли православ'я; готували бідних дітей і сиріт до самостійного життя завдяки навчанню їх різним ремеслам.

Крім чітко встановлених загальних цілей і завдань, що мали виконувати усі братства, у статутах фіксувалися й індивідуальні завдання, що випливали з потреб парафій.

8 травня 1864 р. російський уряд опублікував закон «Основні правила для заснування православних церковних братств», які визначали основні засади їх діяльності ${ }^{8}$.

\footnotetext{
${ }^{4}$ Григорук О. До історії православних церковних братств Поділля (за матеріалами «Подольских епархиальных ведомостей»). Наукові записки. Збірник праць молодих вчених та аспірантів. Київ, 2008. С. 234-242.

${ }^{5}$ Oпря I. Місіонерська діяльність православних братств у Правобережній Україні у 60-ті роки XIX - на початку XX ст. Гілея: науковий вісник. Збірник наукових пращь. 2012. Вип. 65. С. 44-47.

${ }^{6}$ Сергієнко B. Становлення мережі православних церковних братств Лівобережної України у другій половині XIX ст. - на початку XX ст. Гуржіївські історичні читання. 2013. Вип. 6. С. 219.

${ }^{7}$ Девятисотлетие православия на Волыни 992-1892 гг.: [В 2 ч.]. Житомир: Тип. Литорг. Е.П. Льва, 1892. С. 145.

${ }^{8}$ Центральний державний історичний архів України (ЦДІАК). Ф. 127. Оп. 668. Спр. 489. Арк. 229-231зв.
} 
У документі вказувалося, що кожне братство мало ухвалити статут, в якому зазначалися цілі та завдання, права й обов'язки членів, фіксувалися склад ради братства, засоби та управління справами, фінансування, права й обов'язки, які покладалися на членів ${ }^{9}$.

Реєстрація статуту братств відбувалася відповідно до встановленої процедури. Спочатку його проект подавався на розгляд Подільській духовній консисторії, яка мала винести відповідне рішення. Коли не виникало жодних заперечень, тоді консисторія передавала даний документ на погодження єпископу. Якщо архієрей не виявляв жодних підстав у відмові, тоді він передавав проект статуту для очільника губернії.

Після погодження губернатором, єпископ затверджував статут, що слугувало приводом для офіційного відкриття братства. У разі, якщо консисторія виявляла у ньому певні наявні порушення встановлених вимог, тоді проект статуту повертали для виправлень висловлених зауважень.

Церковні братства мали чітку організаційну структуру. Їхніми членами могли бути особи чоловічої та жіночої статі незалежно від стану та звання, які поділялися на почесних, дійсних (пожиттєвих і річних), засновників і змагальників. За рішеннями загального зібрання до почесних членів зараховували осіб, котрі зробили особливі послуги чи проводили корисну діяльність, або здійснювали значні пожертви близько 100 руб. одноразово чи 10 руб. щороку. Дійсними вважали осіб, котрі щороку вносили в касу 3 руб. або 25 руб. одноразово. Інші члени братства щорічно вносили в касу 30 коп., а ті, що мали намір мати право дорадчого голосу на загальних зібраннях чи займати у ньому певну посаду, вносили не менше 1 руб. Член братства, який не сплатив внески за два роки, позбавлявся звання братчика ${ }^{10}$.

За таким принципом функціонувало і православне братство у м. Кам'янці, засноване у 1865 р. У 60-х рр. XIX ст. простежується зростання кількості православних братств на території Подільської губернії. Зокрема, у 1868 р. функціонувало 9 братств: Кам'янецьке Іоанно-Предтеченське, Гусятинське Кам'янецького повіту, у с. Великі Вербки Ольгопольського повіту, с. Кривохижинець Могилевського повіту, Ямпольське Ямпольського повіту, Балтське, Чернеченське і в с. Плоска Забузька Балтського повіту, Немирівське Брацлавського повіту ${ }^{11}$.

На сторінках «Подольских епархиальных ведомостей» зазначалося, що заснування православних братств для Подільської єпархії стало результатом «відновлення старих братств, що до цього часу зберегли свої відголоски, хоча ці братства можливо, через брак засобів, через бідність братчиків та інших причин, не могли мати в парафіях широкого впливу». Відтак у багатьох парафіях збереглися поодинокі відгомони діючих братств 3 особливими звичаями. Зокрема, віруючі зберігали у церквах свічі, які використовували під час богослужінь у святкові дні, панахид і молебнів, поховань ${ }^{12}$.

Дослідник А. Задорожнюк зазначає, що на основі давніх громадських об'єднань

\footnotetext{
${ }^{9}$ Об основных правилах для учреждения православных церковных братств. Подольские Епархиальные Ведомости. 1864. № 18. С. 215-219.

${ }^{10}$ О правилах для учреждения православных церковных братств. Подольские епархиальные ведомости. 1864. №14. С. $143-145$.

${ }^{11}$ Троищкий П. О братствах в Подольской епархии. Подольские епархиальные ведомости. 1868. № 14. С. 116.

${ }^{12}$ Ibid. C. 117.
} 
ремісників єпархіальна влада сформувала церковні братства у Подільській губернії. Братство при Кам'янецькому кафедральному соборі у 1865 р. за своєю структурою нагадувало організацію ремісничого цеху. Воно мало свою хоругву із зображенням храмового святого, свої 12 воскових свічок, окрему скриньку в храмі та печатку ${ }^{13}$.

Статут Кам'янецького братства затвердив 21 листопада 1864 р. єпископ Холмський і Варшавський Леонтій. Братство знаходилося під безпосереднім покровительством єпископа Подільського і Брацлавського та очільника губернії. До його складу входили дійсні члени, які мали право голосу під час зібрань, і жертводавці. Рада складалася із старшини, який керував радою, двох товаришів, діловода, скарбничого та семи членів. Братство вибирало кандидатів на випадок вибуття чи відсутності дійсних членів ${ }^{14}$.

у 1874 р. було укладено новий статут Кам'янецького православного братства. У ньому фіксувалося, що жертводавці одноразово вносили пожертви грошима чи речами, а також приймали особисту участь «добровільною безоплатною працею» у справах братства. Дійсні члени вносять щорічно 3 руб. і сприяють «добровільною працею, порадою та участю в обговоренні справ братства». До складу ради входили старшина, два товариші і сім членів (два від духовенства, двоє чиновників, троє представників від міста ${ }^{15}$.

У січні 1897 р. було створено комісію для перегляду та внесення змін до діючого статуту, щоб надати діяльності братства більш широкого та доцільного напрямку.

Відповідно до Статуту, затвердженого 22 грудня 1883 р., справами керувала рада, до якої входив дамський комітет (який у 1894 р. був закритий). До рада входили двоє старшин (з духовної та світської частини), двоє товаришів старшин, два члени від духовенства, два чиновники, три члени від міста, яких вибирали терміном на 1 рік.

Згідно нових змін рада складалася зі старшини, товариша голови, двох членів зі складу єпархіальної училищної ради, трьох членів, котрих обирали на два роки на загальних зборах братства. Відзначимо, що за цим проектом зменшувалося виборне право і рада братства отримувала статус адміністративної установи. Пункти стосовно складу, членів і зібрань залишилися тими ж. Попереднє завдання визначалося як «турбота про виховання та освіту сиріт і дітей бідних батьків православного віросповідання в дусі істинно православного благочестя». У новій редакції завдання дещо конкретизувалися, зокрема братство мало піклуватися про утримання братської школи, про заснування церковнопарафіяльних шкіл та їх матеріальне забезпечення ${ }^{16}$.

у статуті Летичівського Свято-Михайлівського братства зазначалося, що його ціллю є підтримувати інтереси «православ'я російської народності серед різновірного населення м. Летичева». Члени братства складалися з почесних осіб, які зробили значні послуги; пожиттєвих, що пожертвували не менше 50 руб.; дійсних, котрі щорічно

\footnotetext{
${ }^{13}$ Задорожнюк А.М. Ремісниче і фабрично-заводське виробництво у Подільській губернії у XIX ст.: історичний аспект: дис... к. іст. н.: 07.00.01; Кам'янець-Подільський держ. ун-т. Кам'янець-Подільський, 2007. С. 114.

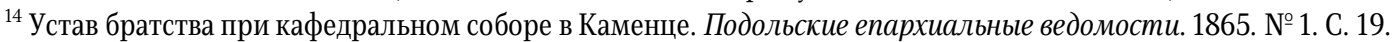

${ }^{15}$ Устав православного Иоанно-Предтеченского братства при кафедральном соборе в г. Каменце, вновь составленный его Высокопреосвященством Леонтием архиепископом Подольским и Брацлавским, 5 июля 1874 года. Подольские епархиальные ведомости. 1874. № 19. С. 532.

${ }^{16}$ Проект нового устава Иоанно-Предтеченского братства и положение о братской школе. Подольские епархиальные ведомости. 1897. № 39. С. 1054.
} 
сплачували внески не менше 3 руб. і благодійників, які здійснювали сприяння братству матеріальними пожертвуваннями у незначних розмірах. Управління справами здійснювалося радою братства, до якої входили старшина, два представники від духовенства, два чиновники і троє 3 місцевого населення ${ }^{17}$.

У статуті Ямпольського братства прослідковувалися деякі особливості, що полягали у тому, що кожний із засновників братства вважався одночасно і його членом ${ }^{18}$.

На початку XX ст. відбулася реорганізація у діяльності діючих братств, тому було складено та запропоновано нову редакцію статуту для парафіяльних братств. У проекті зазначалося, що «братства піклуються про підняття у парафіях християнського православного просвітництва і моральності, спостерігають за станом віри і сприяють усуненню недоліків релігійно-морального життя вірян власним прикладом i розтлумаченнями». Вони дбали про викорінення пияцтва, розгулу, лихослів', сварок та інших поганих звичаїв. Члени спостерігали за станом сектантства у місцевості та своєю діяльністю попереджали можливість відхилення від православ'я, повідомляли парафіяльного священика про усі важливі події із життя сектантів, «про способи спокушання ними православних». Братство турбувалося про відкриття бібліотеки та забезпечення її книгами духовно-морального змісту, купувало та розповсюджувало книги і брошури протисектантського змісту серед православних і сектантів для читання. Члени влаштовували у віддалених від храму поселеннях каплиці чи молитовні будинки, в яких священик здійснював богослужіння чи проводив позабогослужбові бесіди. Члени турбувалися про бідних і малозабезпечених, сиріт і престарілих у парафії та допомагали грошами чи одягом, їжею, надавали притулок тим, хто навертався із сект у православ'я. Ще одним аспектом був пошук приміщення й організація позабогослужбових читань і публічних бесід не лише для віруючих, а й для сектантів. Справами братства керувала рада, яка складалася із чотирьох членів, обраних на загальних зібраннях терміном на три роки, і священика, який був головою. Наявні кошти витрачалися на: облаштування храму, допомогу нужденним, облаштування благодійних установ, заснування школи та бібліотеки, поховання померлих, розповсюдження брошур і листівок ${ }^{19}$.

На початку ХX ст. було прийнято новий статут, що регулював діяльність православних парафіяльних братств Подільської губернії. Відповідно до даного документу основними завданнями братств визначали: об'єднання з релігійно-моральною метою кліру і прихожан, піклування про зміцнення в парафіях православної віри i «розвиток російської самосвідомості», турбота про виконання братчиками і віруючими релігійно-моральних обов'язків, турбота про облаштування храмів, благоустрій кладовищ і церковнопарафіяльних будівель, здійснення «морального впливу на осіб, котрі вагалися у православ'ї та навернулися в інші віросповідання».

Крім того, братчики мали закуповувати та розповсюджувати серед народу книги, брошури та листки релігійно-морального змісту й інших корисних видань,

\footnotetext{
${ }^{17}$ Центральний державний історичний архів України. Ф. 442. Оп. 663. Спр. 12. Арк. 243-245.

${ }^{18}$ Церковное православное братство при Ямпольском Градском соборе. Подольские епархиальные ведомости. 1868. № 12. С. 375.

${ }^{19}$ Проект устава приходских братств или обществ ревнителей православия в местностях, имеющих сектантов. Вольнские епархиальные ведомости. 1903. № 20. С. 582.
} 
організовувати та підтримувати при церквах церковні хори й вводити там загальнонародний спів, здійснювати пошук шляхів отримання матеріальних коштів на відкриття та підтримку шкіл, бібліотек, лікарень і притулків. Важливим аспектом було виділення коштів для отримання подальшої освіти обдарованих дітей, що закінчили курси при початкових школах парафії, надання матеріальної допомоги та моральної підтримки для збіднілих і потерпілим від нещасних випадків.

Управління справами покладалося на раду братства і загальні збори. Головою ради призначався священик парафії, а його члени вибиралися на загальних зібраннях братства і називалися «старшими братчиками і старшими сестрами» ${ }^{20}$.

До ради братства входили голова, чотири члени і три кандидати до них. На загальному річному зібранні вирішували наступні питання: вибирали або підтверджували у своєму званні старші братчики та члени ради, скарбник і його помічник; перевіряли братську касу згідно з книгою надходжень і витрат та засвідчували дану перевірку підписом голови і членів ради; збирали та фіксували зібрані членські внески на наступний рік до книги надходжень; обговорювали питання про потреби братства та пошуку нових грошових надходжень для майбутніх витрат.

За необхідності, крім річного зібрання, голова проводив чотири рази на рік загальні зібрання братчиків. На них обговорювали питання, що мали винятково важливе значення та стосувалися не лише інтересів самого братства, але й парафії у цілому, зокрема подій, що порушували звичайний плин життя відповідно до визначених завдань братства.

Крім загальних зібрань, у першу неділю кожного місяця після молебню, обов'язково скликали чергові зібрання ради братства для обговорення поточних питань, що стосувалися церковнопарафіяльного життя згідно визначених завдань братства. Такі ж зібрання могли організовувати у будь-який час для розгляду екстрених випадків чи справ такого ж змісту. Ці зібрання могли відвідувати й інші члени братства, що мали право дорадчого голосу.

Обіг ведення документів радою братства фіксувався у книзі, яка поділялася на три розділи: 1) «братська книга», 2) «пом'янник» живих, померлих членів і благодійників, 3) братський щоденник. «Братська книга» складалася 3 двох частин, де у першій зазначалися ім'я, прізвище кожного братчика, вік, час його вступу, місце проживання, щорічна оплата членських внесків, і час виходу із складу братства із зазначенням причин. Друга частина слугувала книгою надходжень і витрат, в якій все майно братства поділялося на готівкові кошти, пожертвування речами й отримання коштів від державних паперів. У «братський щоденник» записували короткі замітки стосовно питань і постанов, що виникали під час зборів ${ }^{21}$.

Під час розгляду духовною консисторією 1914 р. даного статуту, Свято-Троїцьке братство відзначило зазначений статут як такий, що за своїм змістом «відповідає запитам часу, а за своєю доцільністю повною мірою придатним для всіх церков Подільської єпархії» і висловило внести в нього певні виправлення. Зокрема, у цих доповнення зазначалося, що покровителем і попечителем братства є Подільський єпископ, котрий має право бути присутнім на усіх засіданнях в якості почесного голови, а також

\footnotetext{
${ }^{20}$ Державний архів Хмельницької області (ДАХО). Ф. 318. Оп. 1. Спр. 9280. Арк. 1.

${ }^{21}$ ДАХО. Ф. 318. Оп. 1. Спр. 9280, Арк. 1 3в, 7.
} 
присилати від себе довірену особу в якості представника. у пункті 2 пропонували зазначити, що членами можуть бути особи православного віросповідання, що досягли громадянського повноліття (21 рік). Пропонувалося у розділі «Управління справами братства» додати наступне: «відкриття та закриття братства здійснюється 3 відома та дозволу Подільського єпископа». Зміни внесли і до останнього пункту, зазначивши, що «у випадку розділення голосів при вирішенні важливого питання, що має значення для усієї парафії, рада братства дане питання виносить на розгляд владики» ${ }^{22}$. Даний статут у доповненому вигляді був затверджений губернатором 10 липня 1910 р.

Отже, підсумовуючи дане питання, відзначимо, що у Подільській губернії діяли православні церковні братства, діяльність яких регулювалася законодавчими документами російського уряду. Відтак це впливало на те, що діяльність братств контролювалася не лише церковними, а й державними установами. Такий контроль призводив до того, що братства повинні були свою діяльність спрямовувати на зміцнення позицій православ'я в губернії. Діяльність братств офіційно розпочиналася після затвердження статутів, які мали бути схвалені керівництвом єпархії та губернатором. У цих статутних документах фіксувалися основні завдання, обов'язки членів, напрями роботи. Наприкінці XIX ст. діяльність окремих братств почала занепадати, окремі з яких згортали свою діяльність через складне матеріальне становище. Проте єпархіальне керівництво докладало нових зусиль для активізації та відродження старих братств. Відповідно на початку XX ст. єпархією було розроблено новий зразок статуту, що регулював діяльність братств губернії. У своїй основі він повторював попередній, лише містив незначні доповнення. Відповідно до завдань, які покладалися російським урядом на братства, вони мали стати активними «захисниками православної віри», протистояти поширенню та насадженню ідей не тільки католицизму, а й протестантських конфесій у губернії. Братства не могли вільно реалізовувати свою діяльність, оскільки вона залежала від суворо визначених приписів і дозволів церковного управління. Таким чином, діяльність братств обмежувалася та не мали власного волевиявлення.

\section{Oksana Alyoshina}

\section{Organizational Principles of Activity of Orthodox Church Fraternities of Podilsk Province (second half of XIX - early XX century)}

Abstract: The purpose of the article is to reveal the organizational foundations of the functioning of the Orthodox fraternities of the Podolsk province during the second half of the XIX - early XX centuries. Scientific novelty - for the first time on the basis of little-known archival documents the specifics of organizational design and functioning of Orthodox fraternities of Podolsk province are analyzed and revealed.

Conclusions. It is established that during the second half of the XIX century. Circumstances of the establishment and further activity of Orthodox fraternities in the territory of Podolsk province were regulated by such a legislative normative document as

${ }_{22}^{2}$ ДАХО. Ф. 318. Оп. 1. Спр. 9280. Арк. 7-8зв. 
«Basic rules for the establishment of Orthodox church fraternities». This document defined and controlled the tasks, composition, activities of the fraternities in the early XX century. The socio-political life of the Russian Empire underwent certain changes, which, in turn, affected the position of the Orthodox fraternities of the Right Bank of Ukraine. This made some adjustments and, in particular, the church administration of the Podolsk diocese concluded and approved new rules governing the further work of Orthodox fraternities.

The Russian government assigned new tasks to the fraternities, according to which they were to become active "defenders of the Orthodox faith», to oppose the spread and implantation of the ideas of Catholicism and Protestantism. At the same time, the Brotherhoods could not freely carry out their activities. It depended on strictly defined regulations and permits of the church administration. Thus, the activities of the fraternities were limited and did not have their own will.

Keywords: Russian government, orthodox fraternities, organizational principles, charter, Podolsk province 